\title{
Implementasi Pendidikan Budi Pekerti Dalam Menanggulangi Kenakalan Siswa
}

\author{
Siti Fatimah, Nurul Zuriah, M Syahri \\ FKIP Universitas Muhammadiyah Malang, Indonesia \\ Email: Cewekmerpati@rocketmail.com
}

\begin{abstract}
The purpose of this study is: (1) To identify and describe the implementation of character education in addressing student misbehaviour in SMP Negeri 8 Malang. (2) To identify and describe the factors that cause delinquency students in SMP Negeri 8 Malang. (3) To determine and describe the obstacles and supporting elements in the face in the implementation of character education in dealing with student misbehaviour in SMP Negeri 8 Malang. (4) To identify and describe the solutions taken by the school to address the factors inhibiting the implementation of character education in dealing with student misbehaviour in SMP Negeri 8 Malang. This study uses qualitative research techniques. Where researchers go directly into the field to gather information related to the title of the review. The data collection was obtained by interview, observation and documentation. The informant information that needs to be explored is the principal, teachers PPKn SMP Negeri 8 Malang, Islamic Teacher SMP Negeri 8 Malang, Teacher Guidance Counseling (BK) SMP Negeri 8 Malang, and informant of class VII students of SMP Negeri 8 Malang. Based on research conducted by researchers at SMP Negeri 8 Malang The results obtained are (1) Implementation of character education in dealing with student misbehaviour in SMP Negeri 8 Malang in accordance with the Vision and Mission of SMP Negeri 8 Malang, and through all subjects and extracurricular activities through SMP Negeri 8 Malang. (2) Causes of Delinquency students occurrence due to the influence of the external environment that influences society and the mass media technology and increasingly sophisticated. (3) Obstacles and Supporting implementation of character education in dealing with student misbehaviour in SMP Negeri 8 Malang is, the inhibiting factor because fulgar outside media such as the internet and the mass media that children easy access to the things that cause the destruction of morals of the nation while the supporting factors of all components of the school is good that all the teachers and administrative staff who have been part of the support. (4) The solution in overcoming factors inhibiting the implementation of character education that is conducted by the school SMP Negeri 8 Malang is to be arranged in the system, the role of government itself must care for the child as a future asset, and there must be cooperation between all the components in schools SMP Negeri 8 Malang.
\end{abstract}

Keyword: Character Education; Implementation; Students Delinquency

\section{PENDAHULUAN}

Berbicara mengenai kenakalan siswa adalah masalah yang dirasa sangat penting dan menarik untuk dibahas dan juga harus ditangani secara terpadu dan menyeluruh. Hal ini disebabkan pada masa remaja merupakan suatu tahap kehidupan yang bersifat peralihan dan masa kegoncangan yang sangat menentukan keadaan masa depannya, atau masa pencarian jati diri, dimana pada usia SMP adalah masa-masa pubertas awal yang dialami siswa dalam kehidupannya.
Kualitas kehidupan manusia pada suatu bangsa dewasa ini adalah sangat ditentukan oleh kualitas para pemudanya, bahkan ditentukan oleh kualitas anakanaknya. Oleh karena itu tuntutan akan pendidikan dewasa ini semakin meningkat di karenakan dorongan yang sangat kuat untuk perkembangan ilmu pengetahuan dan teknologi yang semakin maju untuk memenuhi kebutuhan hidup yang sedemikian rupa, maka tidak bisa diabaikanbahwapendidikanitumemegang peranan penting dalam menghadapi 
perkembangan ilmu pengetahuan dan teknologi. Tujuan dari pendidikan itu akan mudah tercapai manakala para pemudanya secara sadar memahami pentingnya suatu pendidikan. Namun dewasa ini, banyak di lihat keanekaragaman kenakalan yang dilakukan para siswa terutama siswa SMP sehingga berdampak pula pada tercapainya tujuan pendidikan tersebut.

Kenakalan yang dilakukan para siswa bisa juga di sebut dengan delinquency siswa, dimana dalam konsep psikologi delinquency berarti kejahatan atau kenakalan. Sekaitan dengan ini pembatasan dari para ahli hukum Anglo Saxon dapat diterima, bahwa delinquency siswa berarti perbuatan dan tingkah laku yang merupakan perbuatan perkosaan terhadap norma hukum pidana dan pelanggaran-pelanggaran terhadap kesusilaan yang dilakukan oleh anakanak remaja. Sehari-hari sering didengar bahwa anak-anak yang suka berkelahi dan bertengkar sesama kawannya serta mengeluarkan perkataan yang kotor adalah anak nakal. Apabila di klasifikasikan secara keseluruhannya, maka ini menimbulkan suatu pengertian "kenakalan anak-anak". Jika yang dipersoalkan sekarang ialah tentang perbuatan kenakalan, maka yang manakah dan yang bagaimanakah yang dirasakan merupakan "kenakalan anak" tersebut, sehingga perlu ditanggulangi secara serius yang mendalam oleh tiap negara.

Melihat perkembangan jaman yang sangat pesat ini menyebabkan terjadinya suatu era globalisasi. Di era globalisasi terjadi banyak sekali perubahan baik dari di bidang ekonomi, teknologi, budaya dan sosial, yang mana sangat berpengaruh dalam perilaku seseorang di lingkungan masyarakat. Disini akan dibahas perubahan yang dialami di lingkungan sekolah yang berdampak negatif. Perubahan pada era globalisasi mempunyai dampak positif maupun dampak negatif akibat dari perubahan itu sendiri. Salah satu contoh perubahan pada bidang budaya misalnya, bila dibandingkan antara budaya bangsa Indonesia jaman dahulu dengan jaman sekarang terlihat sangat berbeda. Perbedaan itu terletak pada sopan santun dalam berperilaku di masyarakat.

Bangsa Indonesia pada jaman dahulu sering disegani oleh bangsa-bangsa luar negeri karena mempunyai budaya malu yang mana budaya menjaga untuk selalu berperilaku sopan santun, ramah tamah, etika bertatakrama yang baik antara anak dengan orang tua, siswa dengan guru, antar sesama teman, sampai dengan bersosialisasi di masyarakat dan ketika ada masalah atau unek-unek yang ingin disampaikan maka diselesaikan dengan cara musyawarah untuk mufakat biasanya di pedesaan dinamakan rembuk desa. Jika dibandingkan dengan budaya bangsa Indonesia jaman sekarang sangat beda jauh, ini dapat di lihat dari berbagai sumber informasi media massa seperti koran dan media elektronik seperti televisi, radio, internet, mengenai pemberitaan tentang perilaku jaman sekarang terjadi kenakalan siswa. Contoh yang sering terjadi akhir-akhir ini terjadi melanggar aturan yang berlaku, tawuran antar pelajar sampai merambat antar mahasiswa, demo yang kerap kali merusak fasilitas umum, merokok pada tingkat, rambut disemir, bermain motor ugal-ugalan dijalan raya, perkelahian, pencurian, sampai pada tingkat ekstrim narkoba, sabu-sabu, ganja, minumminuman keras, seks bebas, pencabulan, pemerkosaan, hingga menghilangkan nyawa orang lain sekolah yang terjadi adalah perubahan yang berdampak positif maupun negatif. Kenakalan yang di lakukan siswa ini sungguh meresahkan teman, guru, kepala sekolah, orang tua, dan masyarakat.

Perilaku ini akan membawa dampak yang negatif terhadap dirinya sendiri dan orang lain maupun temannya. Inilah yang membuat resah guru, orang tua dan masyarakat. Kenakalan siswa ini 
diibaratkan seperti penyakit yang mudah menular kepada siswa lainnya. Karena pada diri siswa tersebut kurang adanya kontrol diri dan pengetahuan yang masih minim tentang budi pekerti. Penyebab kenakalan siswa adalah kurangnya perhatian dan kasih sayang dari lingkungan keluarga, dimana peran orang tua sangatlah dibutuhkan. Ini juga disebabkan akibat dari perceraian orang tua atau istilah yang sering kita dengar "broken home". Perceraian orang tua ini akan membuat siswa tersebut merasa tidak ada yang peduli dengannya sehingga dengan mencari perhatian serta minimnya penanaman nilai dari orang tua maka menyebabkan kenakalan pada seorang siswa, karena keluarga adalah tempat pertama dan utama terbentuknya suatu perilaku moral dari seorang siswa.

Banyak terjadi kenakalan siswa di sekolah akibat kurang ketatnya pengawasan dari guru, tata tertib sekolah yang kurang ditaati oleh siswa karena siswa cenderung acuh pada peraturan karena lemahnya penegakan peraturan tersebut. ada juga yang beranggapan dari seorang siswa jika melakukan kenakalan maka akan merasa "cool" atau bangga, ini adalah bentuk seorang siswa yang mencari perhatian dari temannya atau guru-guru. Karena siswa tersebut kurangnya perhatian dan kasih sayang dari orang terdekatnya bisa orang tua, teman, dan guru. Banyak aspek yang menyebabkan kenakalan ini terjadi pada seorang siswa, perlu pertahanan yang kuat supaya kenakalan seorang siswa merupakan hal yang wajar-wajar saja dan dapat diminimalisir. Memang setiap orang atau anak ini mempunyai sikap berbeda-beda dan tentunya mempunyai kepribadian yang berbeda beda ini dari gen bawaan, lingkungan keluarga, lingkungan masyarakat sekitar, dan keadaan suatu Negara ini semua bisa mempengaruhi keadaan psikis seorang anak.

Kenakalan siswa ini jika dibiarkan saja dan jika anak atau siswa tersebut tumbuh dewasa ini akan menjadi bom atom yang siap meledak atas kenakalan seorang siswa karena tanpa adanya tindakan preventif dari guru, pihak sekolah, orang tua, masyarakat, dan Negara. Untuk meminimalisir kenakalan remaja ini perlu adanya kerjasama antara guru, pihak sekolah, orang tua, masyarakat, dan Negara. Peran orang tualah yang berperan lebih karena orang tua lebih peka terhadap anaknya, dan juga seorang guru sebagai pendidik harus mencari solusi ketika masalah atau rumor tentang kenakalan siswa ini bisa diatasi dengan adanya suatu teladan dan pendidikan yang diajarkan di sekolah, karena tugas guru adalah mendidik dan bisa merubah sikap siswa menjadi lebih baik, jadi tidak hanya transfer knowledge atau ilmu pengetahuan. Disini peran Negara dalam membuat peraturan perundang-undangan tentang pendidikan moral dan budi pekerti harus jelas, mudah dimengerti oleh masyarakat sehingga peraturan tersebut harus digalakkan dan harus terimplementasi secara terus menerus.

Kegiatan pendidikan di sekolah, sampai saat ini masih merupakan wahana sentral dalam mengatasi berbagai bentuk kenakalan siswa yang terjadi. Oleh karena itu segala apa yang terjadi dalam lingkungan di luar sekolah, senantiasa mengambil tolok ukur aktivitas pendidikan dan pembelajaran sekolah. Hal seperti ini cukup disadari oleh para guru dan pengelola lembaga pendidikan dan mereka melakukan berbagai upaya untuk mengantisipasi dan memaksimalkan kasus-kasus yang terjadi akibat kenakalan siswanya melalui penerapan tata tertib, pembelajaran moral, agama dan norma-norma susila lainnya. Pelajar dan pemuda muslim yang kini merupakan mayoritas kawula muda di Indonesia, wajar dan sangat tepat jika senantiasa membina diri, hingga akhirnya memiliki karakter Islami yang penuh dengan keluhuran dan kemuliaan agar tidak terjebak dalam hal-hal yang dilanggar oleh 
syari'at agama.

Menurut penelitian KOMNAS perlindungan anak Tahun 2013, angka prosentase remaja yang pernah melakukan hubungan seks pra nikah mencapai hingga $62,7 \%, 21,2 \%$ remaja pernah aborsi, $93,7 \%$ remaja SMP dan SMA pernah melakukan ciuman dan oral seks, 97,0\% remaja SMP dan SMA pernah menonton film porno. Sedangkan badan narkotika nasional mencatat jumlah pengguna narkoba di Indonesia mencapai 4.000.000 pengguna dan $20 \%$ diantaranya adalah pelajar, $70 \%$ siswa SMP dan SMA di 12 kota besar pernah mendapatkan tawaran narkoba dari temannya dan 83.000 pelajar pengguna narkoba (SD, SMP, dan SMA) di 12 kota besar. Melihat data di atas, pemerintah berupaya memberikan solusi dengan menawarkan sistem baru yang berupa pendidikan berkarakter yang di dalamnya di tanamkan Budi pekerti dan moral dengan tujuan meminimalisir jumlah prosentase yang banyak terjadi saat ini.

Pendidikan Budi pekerti adalah upaya yang terencana untuk menjadikan siswa mengenal, peduli dan menginternalisasi nilai-nilai sehingga peserta didik berperilaku sebagai insan kamil. Diharapkan dari pendidikan budi pekerti ini, lebih-lebih internalisasi nilainilai Islami, siswa dapat mencontoh sikap nabi Muhammad SAW yang memang menjadi suri tauladan bagi Umat Islam, sebagaimana firman Allah:"Dan ikutilah apa yang diwahyukan Tuhan kepadamu. Sesungguhnya Allah adalah Maha mengetahui apa yang kamu kerjakan". (Q.S. Al-Ahzab (33) : 2).

Seperti halnya dari hasil dokumentasi yang peneliti dapatkan dari Wakasek Kesiswaan dan berdasarkan observasi yang pernah peneliti lakukan pada saat melakukan Praktek Pengalaman Lapangan (PPL), terjadinya kenakalan siswa mulai dari kenakalan di kelas seperti menyontek, membuat gaduh di kelas, mengganggu temannya sedang belajar sampai mengarah perkelahian, pencurian, bahkan banyakjuga ditemukan ketika di luar kelas kenakalan siswanya sebagai berikut: yaitu, kurang cinta tanah air, tidak taat pada aturan, vandalisme, tidak disiplin (berpakaian tidak sesuai aturan, rambut tidak rapi, sepatu tidak warna hitam atau warna wajib, suka terlambat hadir), hingga isu kasus school bullying. Meskipun tidak ditemukan school bullying dalam kategori kontak fisik langsung, namun masih ditemukan school bullying dalam tiga kategori lain, yaitu:

1) Kontak verbal langsung dengan cara mempermalukan, mengganggu, memberi panggilan nama, merendahkan, mengejek, mengintimidasi, memaki dan menyebar gosip.

2) Perilaku non verbal langsung dengan cara melihat dengan sinis, menjulurkan lidah, menampilkan ekspresi muka yang merendahkan, mengejek biasanya disertai oleh bullying fisik atau verbal.

3) Perilaku non verbal tidak langsung dengan cara mendiamkan seseorang, memanipulasi persahabatan sehingga menjadi retak, sengaja mengucilkan atau mengabaikan, mengirimkan surat kaleng.

Beberapa contoh kenakalan siswa yang banyak terjadi di SMP Negeri 8 Malang berdasarkan dokumentasi dari Wakasek Kesiswaan yang ada di SMP Negeri 8 Kota Malang adalah Pacaran, datang terlambat ke sekolah, tidak memakai seragam lengkap, sepatu tidak warna hitam atau warna wajib, rambut tidak rapi, suka menyebar gosip, suka menjaili temannya, mengolok-olok temannya dan suka mengejek gurunya, maka di sinilah kedudukan guru dalam setiap mata pelajaran memiliki peran yang sangat penting dan turut serta mengatasi terjadinya kenakalan siswanya, sebab setiap guru merupakan sosok yang bertanggung jawab 
langsung terhadap pembinaan moral dan menanamkan norma hukum tentang baik dan buruk serta tanggung jawab seseorang atas segala tindakan yang dilakukan baik didunia maupun diakhirat. Namun, tidak hanya guru yang harus terbebani dengan semua ini, segala aspek harus ikut andil dalam mewujudkan pendidikan budi pekerti ini, terlebih orang tua. Sebagaimana firman Allah dalam QS. AT-Tahrim (66) : 6 : "Hai orang-orang yang beriman, peliharalah dirimu dan keluargamu dari api neraka yang bahan bakarnya adalah manusia dan batu; penjaganya malaikat-malaikat yang kasar, keras, dan tidak mendurhakai Allah terhadap apa yang diperintahkan-Nya kepada mereka dan selalu mengerjakan apa yang diperintahkan".

Secara moralistik, pendidikan budi pekerti merupakan salah satu cara untuk membentuk mental manusia agar memiliki pribadi yang bermoral, berbudi pekerti yang luhur. Nilai yang harus ditanamkan adalah kejujuran (shidiq), kasih sayang (arrahman), tidak berlebih-lebihan (qana'ah), menghormati kedua orang tua (birrul walidain), memelihara kesucian diri (aliffah) dan bertaqwa.

Ki Hajar Dewantara mencontohkan di dalam bukunya yang berjudul Pendidikan (1977:487) "Bahwa pendidikan budi pekerti bagi anak-anak kecil, bisa dicontohkan oleh seorang pendidik atau guru dengan cara menganjur atau memerintahkan anak-anak untuk duduk yang baik, jangan berteriakteriak agar tidak mengganggu anak yang lain, bersih badan dan pakaian, hormat terhadap ibu bapak, menolong orang lain yang perlu pertolongan dan sebagainya. Untuk anak yang sudah akhil baligh atau sudah dapat berfikir, yaitu dengan memberi kesadaran tentang berbagai kebaikan dan keburukan namun selalu atas dasar pengetahuan, kenyataan dan kebenaran. Anak-anak yang mulai dewasa dilatih untuk melaksanakan berbagai kebaikan, seperti melatih mereka untuk berpuasa, menahan hawa nafsu. Untuk yang sudah dewasa, mereka diusahakan supaya jangan bersikap sombong atau takabbur, bersikap raguragu (syak) dan kadang-kadang terombangambing oleh keadaan-keadaan yang tidak mereka alami sebelumnya. Mereka harus sudah mengerti akan adanya hubungan antara tata tertib lahir dan kedamaian bathin, dan harus sudah cukup berlatih dan terbiasa untuk mengusai dirinya. Tujuan dari pendidikan budi pekerti itu sendiri ialah membina dan membangun kejiwaan serta keadaan seorang anak, sehingga anak tidak akan terpengaruh oleh lingkungan atau pergaulan yang merugikan dan kalaupun mereka masih juga salah pilih, maka setidak-tidaknya mereka sudah dapat berfikir secara bertanggung jawab dan di dalam diri mereka sudah terbentuk suatu fondamen moral yang baik sebagaimana yang diharapkan.

\section{METODE}

Pendekatan penelitian yang digunakan dalam penelitian ini adalah pendekatan kualitatif. Pendekatan kualitatif adalah pendekatan yang temuan-temuan penelitiannya tidak diperoleh melalui prosedur statistik atau bentuk perhitungan lainnya, prosedur ini menghasilkan temuantemuan yang diperoleh dari data-data yang dikumpulkan dengan menggunakan beragam sarana. Sarana itu meliputi pengamatan dan wawancara, namun bisa juga mencakup dokumen, buku, kaset video, dan bahkan data yang telah dihitung untuk tujuan lain, misalnya data sensus.

Penelitian kualitatif ini menggunakan pendekatan fenomenologis dimana untuk memahami makna dibalik fenomena yang dideskripsikan secara rinci. Tujuan penelitian fenomenologi adalah melakukan pemahaman respon atas keberadaan individu dalam masyarakat, serta pengalaman yang dipahami dalam menjalankan interaksi dengan sesamanya (Fatchan, 2009:64). 
Penelitian tentang "Implementasi Pendidikan Budi Pekerti dalam Menanggulangi Kenakalan Siswa di SMP Negeri 8 Malang" ini, pendekatan yang digunakan adalah pendekatan kualitatif, karena penelitian ini berusaha untuk mendiskripsikan dan menganalisis bagaimana implementasi pendidikan budi pekerti dalam menanggulangi kenakalan siswa di SMP Negeri 8 Malang serta fenomena pengimplementasian pendidikan budi pekerti di SMP Negeri 8 Malang. Seperti yang ditulis Zuriah (2009:92) yang mengatakan bahwa penelitian kualitatif memerlukan ketajaman analisis, objektifitas, sistematis dan sistemik sehingga diperoleh ketepatan dalam interprestasi, sebab akibat dari suatu fenomena atau gejala bagi penganut penelitian kualitatif adalah totalitas atau Gestalt Untuk dapat menemukan data yang sesuai dengan tujuan penelitian.

Pendekatan penelitian kualitatif perhatiannya lebih banyak ditujukan pada pembentukan teori substansif berdasarkan konsep-konsep yang timbul dari data empiris. Dalam penilaian kualitatif, peneliti merasa "tidak tahu apa yang tidak diketahui", sehingga desain penelitian yang dikembangkan selalu merupakan kemungkinan yang terbuka akan berbagai perubahan yang diperlukan dan lentur terhadap perubahan yang diperlukan dan lentur terhadap kondisi yang ada di lapangan. Penelitian kualitatif adalah prosedur penelitian yang menghasilkan data deskriptifberupa kata-kata tertulis atau lisan dari orang-orang dan perilaku yang dapat di amati. Penelitian ini menggunakan pendekatan kualitatif karena : a) lebih mudah mengadakan penyesuaian dengan kenyataan yang berdimensi ganda, b) lebih mudah menyajikan secara langsung.

Jenis penelitian yang digunakan adalah penelitian lapangan. Penelitian lapangan dapat di anggap sebagai pendekatan luas dalam penelitian kualitatif atau sebagai metode untuk mengumpulkan data kualitatif. Ide pentingnya adalah bahwa peneliti berangkat ke lapangan untuk mengadakan pengamatan terhadap suatu keadaan alamiah. Jenis penelitian yang digunakan adalah jenis penelitian yang menghasilkan kata-kata tertulis atau lisan dari orang-orang dan datanya dikumpulkan berupa tulisan, kata-kata, gambar dan bukan angka-angka. Pendekatan ini terikat erat dengan pengamatan-pengamatan berprasyarat (Moleong, 2006: 26). Penelitian kualitatif adalah prosedur penilaian yang menghasilkan data deskriptif berupa kata-kata tertulis atau lisan orangorang dan perilaku yang diamati Bogdan dan Tylor (dalam Zuriah 2007: 92).

Penelitian yang dimaksudkan untuk mengungkapkan gejala secara holistikkontekstual melalui pengumpulan data dari latar alami dengan memanfaatkan diri peneliti sebagai instrumen kunci. Penelitian kualitatif bersifat deskriptif dan cenderung menggunakan analisis dengan pendekatan induktif. Pendekatan dan jenis penelitian kualitatif ini bertujuan untuk mencari data yang berkaitan dengan permasalahanpermasalahan yang menjadi fokus peneliti dalam melakukan penelitian ini.

\section{HASIL DAN PEMBAHASAN}

Setelah melakukan penelitian di SMP Negeri 8Malang, didapatkanhasilpenelitian mengenai Implementasi Pendidikan Budi Pekerti dalam menanggulangi Kenakalan Siswa di SMP 8 Malang yang diperoleh yaitu peneliti ingin mengetahui bagaimana implementasi pendidikan budi pekerti dalam menanggulangi kenakalan siswa di SMP Negeri 8 Malang, di sekolah yang tergolong favorit ini.

\section{Implementasi Pendidikan Budi Pekerti Dalam Menanggulangi Kenakalan Siswa Di SMP Negeri 8 Malang}

Penelitian ini untuk mengetahui tentang implementasi pendidikan budi 
pekerti dalam menanggulangi kenakalan siswa di SMP Negeri 8 Malang. Peneliti melakukan observasi dan wawancara dengan beberapa narasumber dalam mengkaji dan memahami implementasi pendidikan budi pekerti dalam menanggulangi kenakalan siswa di SMP Negeri 8 Malang. Peneliti mendapatkan informasi bahwa implementasi pendidikan budi pekerti sudah berjalan dengan baik. Pendidikan budi pekerti bukan merupakan pendidikan yang mudah untuk di ajarkan, karena pada dasarnya pendidikan ini berkaitan dengan karakter dasar yang dibawa sejak lahir maupun karakter yang telah ditanamkan oleh orang tua yang terkadang berbenturan keras dengan nilai-nilai budi pekerti positif dalam pergaulan sekolah, sehingga implementasi pendidikan budi pekerti harus disesuaikan dengan banyak faktor baik dalam diri siswa (intrapersonal), siswa dengan lingkungan sosial (interpersonal relationship), siswa dengan tuhan (spiritual relationship). Budi pekerti terlihat dalam bentuk perbuatan, perkataan, pikiran sikap, perasaan, dan kepribadian peserta didik.

Budi pekerti adalah nilai nilai yang hidup manusia yang sungguh-sungguh dilaksanakan dan bukan sekedar kebiasaan, tetapi berdasar pemahaman dan kesadaran diri untuk menjadi baik. Sehingga untuk menanamkan budi pekerti pada anak perlu cara yang tepat dan harus di latih sejak dini untuk menghasilkan siswa yang berkualitas dan mempunyai budi pekerti yang luhur. Disimpulkan bahwa secara keseluruhan dari hasil wawancara peneliti dengan informan bahwa mengenai implementasi pendidikan budi pekerti dalam menanggulangi kenakalan siswa itu sudah cukup baik, lancar dan terkendali bahkan banyak sekali kebijakan-kebijakan bahkan pendekatan-pendekatan yang di lakukan oleh sekolah dalam menunjang adanya implementasi pendidikan budi pekerti dalam menanggulangi kenakalan siswa di SMP Negeri 8 Malang, yang di integrasikan juga kedalam budaya sekolah seperti budaya bersih, jujur, sopan dan disiplin bahkan banyak sekali nilai-nilai yang di kembangkan dalam pendidikan budi pekerti di SMP Neegri 8 Malang contohnya nilai-nilai kedisiplinan, kejujuran, saling menghormati orang lain bahkan nilainilai religiusitas baik itu dimasukkan dalam semua mata pelajaran mengenai penanaman pendidikan budi pekerti oleh semua guru bidang studi ataupun melalui kegiatan ekstrakurikuler yang sudah ada, selain dari ekstrakurikuler keputrian, BTQ (Baca Tulis Al-Qur'an), kegiatan membaca do'a dan Asmaul husna setiap pagi sebelum pelajaran di mulai, kegiatan membaca surah al-waqi'ah dan kultum setiap jum'at bagi yang muslim, sedangkan bagi yang non-muslim dengan mewajibkan membaca kitabnya masing-masing, semua itu untuk mendukung dan menunjang adanya pelaksanaan pendidikan budi pekerti dalam menanggulangi kenakalan siswa di SMP Negeri 8 Malang, bahkan menurut beberapa informan dan juga menurut siswa di SMP Negeri 8 Malang implementasi pendidikan budi pekerti di SMP Negeri 8 Malang ini dilaksanakan juga melalui kegiatan ekstrakurikuler lainnya diantaranya:

a. Kegiatan Ekstrakurikuler Pramuka kegiatan pramuka, siswa dapat dilatih dan dibina untuk mengembangkan diri dan meningkatkan semua perilaku positif siswa. Misalnya, melatih untuk disiplin, jujur, menghargai waktu, tenggang rasa, baik hati, tertib, penuh perhatian, tanggung jawab, pemaaf, peduli, cermat dan lain-lain. Pramuka menjadi salah satu kegiatan untuk melatih siswa untuk mandiri dan bertanggung jawab.

b. Kegiatan Ekstrakurikuler Palang Merah Remaja (PMR)

Kegiatan ini dapat menumbuhkan rasa kepedulian kepada sesama 
apabila ada korban kecelakaan di jalan raya atau karena tertimpa suatu musibah. Selain itu, juga Memiliki dan Mengembangkan sikap Toleransi serta melatih kecakapan sosial dan jiwa sosial kepada sesama.

c. Kegiatan Ekstrakurikuler Olahraga Olah raga mengajarkan nilai sportivitas dalam bermain. Menang ataupun kalah bukan menjadi tujuan utama, melainkan nilai kerja dan semangat juang yang tinggi serta Menumbuhkan kejujuran dan kebersamaan dapat dibentuk melalui kegiatan ini.

d. Kegiatan Ekstrakurikuler Paskibra Melalui kegiatan ini siswa dapat memahami makna yang sebenarnya mengenai Kerja Kelompok (team work) pengembangan mental dan cara berpikir. Serta etos kerja merupakan sebuat wadah di mana semua siswa dapat mengembangkan kemampuan diri. Menambah kemampuan diri, dan meningkatkan kepercayaan diri. Dalam kegiatan ini, siswa dapat mengembangkan dan mengasah kemampuan, ketertiban, ketegasan dan berminat dengan seluk beluk bendera dan berminat ingin mengibarkan bendera merah putih sebagai pemuda dan pemuda Indonesia yang cinta tanah air.

e. Kegiatan Ekstrakurikuler Karate Melalui kegiatan ini siswa dapat menemukan jati dirinya masingmasing, menghargai diri-sendiri, bisa mengendalikan diri dan tentunya mau mengembangkan potensi diri dan untuk mempertahankan, menjaga fisik atau mentalnya dari gangguan dari luar dan tentunya siswa memiliki rasa kesetiakawanan terhadap sesama.

Melalui beberapa ekstrakurikuler itulah pelaksanaan pendidikan budi pekerti dilaksanakan dan di kembangkan di SMP
Negeri 8 Malang untuk menanggulangi kenakalan siswanya, sehingga sampai dengan saat ini semua itu terlaksana dengan baik dan lancar dalam pengimplementasian pendidikan budi pekerti di SMP Negeri 8 Malang ini.

\section{Faktor Penyebab Kenakalan Siswa di SMP Negeri 8 Malang}

Secara keseluruhan dari hasil wawancara peneliti dengan para informan mengenai faktor-faktor penyebab kenakalan siswa di SMP Negeri 8 Malang ini sesuai dengan sebagaimana yang sudah peneliti bahas dalam kajian teori, sehingga disini dapat peneliti simpulkan semua informan mengatakan bahwa faktor-faktor yang menyebabkan kenakalan siswa di SMP Negeri 8 Malang disebabkan karena faktor berikut :

a. Lingkungan Keluarga (Orang tua) Hasil dari beberapa penelitian menunjukkan bahwa anak/siswa yang dibesarkan dalam lingkungan sosial keluarga yang tidak baik atau disharmoni keluarga, maka resiko anak untuk mengalami gangguan kepribadian menjadi berkepribadian antisosial dan berperilaku menyimpang lebih besar dibandingkan dengan anak yang dibesarkan dalam keluarga sehat atau harmonis (sakinah).

b. Lingkungan Sekolah

Kondisi sekolah yang tidak baik dapat menganggu proses belajar mengajar anak didik, yang pada gilirannya dapat memberikan peluang pada anak didik untuk berperilaku menyimpang. Misalnya, kurikulum sekolah yang sering berganti-ganti, muatan agama/budi pekerti yang kurang. Dalam hal ini yang paling berperan adalah kepala sekolah, guru Agama, guru PKn dan Bimbingan Konseling, meskipun semua elemen sekolah bertanggung jawab atas perilaku anak di sekolah. 
c. Lingkungan/Kondisi Masyarakat (Lingkungan Sosial)

Faktor kondisi lingkungan sosial yang tidak sehat atau rawan, merupakan faktor yang kondusif bagi anak/peserta didik untuk berperilaku menyimpang. Dikalanganmasyarakat sendiri sudah sering terjadi kejahatan seperti pembunuhan, penganiayaan, pemerkosaan, pemerasan, gelandangan, dan pencurian. Bagi anak remaja keinginan berbuat jahat kadang timbul karena bacaan, gambar-gambar dan film. Kebiasaan membaca buku yang tidak baik (misal novel seks), pengaruh tontonan gambar-gambar porno serta tontonan film yang tidak baik dapat mempengaruhi jiwa anak untuk berperilaku negatif.

Faktor Penghambat Dan Penunjang yang dihadapi Dalam Implementasi Pendidikan Budi Pekerti Dalam Menanggulangi Kenakalan Siswa Di SMP Negeri 8 Malang

Implementasi pendidikan budi pekerti dalam menanggulangi kenakalan siswa di SMP Negeri 8 Malang pada tataran praksisnya sudah ada dan berjalan namun setiap program yang berjalan biasanya tak lepas ada suatu suatu dukungan dan kendala yang terjadi. Tentu dukungan yang dimaksud adalah faktor pendukung yang menjadi point berjalannya program yang ada sedangkan yang menjadi kendala adalah faktor penghambat yang dapat menghambat jalannya program sekolah. Dengan demikian peneliti ingin mengetahui apa saja yang menjadi faktor pendukung dan penghambat dalam implementasi pendidikan budi pekerti dalam menanggulangi kenakalan siswa yang telah dilakukan di SMP Negeri 8 Malang.

Pendidikan secara umum banyak dihadapkan dengan faktor penghambat dan tidak lepas juga dari faktor penunjang dalam upaya pencapaian tujuan pendidikan nasional, begitu juga dalam pendidikan budi pekerti yang dalam era kontemporer seperti ini menjadi perhatian penting disela arus globalisasi yang tak terkendali. Faktor penghambat itu umumnya berasal dari ketidakmampuan siswa untuk memfilterasi nilai buruk dari arus kehidupan yang sangat dinamis ini. Tak jarang guru memiliki paradigma berbeda-beda dalam nilai, norma yang patut dan tidak patut. Perlu adanya kesepakatan antara satu pihak dengan pihak lain dalam upaya menunjang pendidikan budi pekerti di SMP 8 ini untuk menanggulangi kenakalan siswanya.

Dari beberapa pernyataan para informan mengatakan bahwa lingkungan keluarga (orang tua) dan lingkungan luar (masyarakat) bahkan melalui media massa adalah merupakan faktor penghambat terhadap implementasi pendidikan budi pekerti dalam menanggulangi kenakalan siswa di SMP 8 ini, sedangkan faktor penunjangnya adalah tidak lepas dari peran semua guru di SMP Negeri 8 Malang termasuk guru setiap bidang studi yang sudah mengembangkan dan mengajarkan tentang pentingnya pendidikan budi pekerti pada anak sehingga membentuk anak yang berbudi pekerti luhur. Sehingga disinilah peran dari sekolah atau guru itu sendiri, karena keluarga yang secara tradisional merupakan guru pertama dari setiap anakanak, mulai kehilangan fungsinya. Dengan demikian, terjadi sejenis kekosongan (vacuum) moral di dalam perkembangan hidup anak. Perceraian menjadi sesuatu yang biasa dan akan sangat memukul kehidupan emosional anak serta menjadi perangsang bagi kelainan kelakuan seperti berbagai jenis kenakalan yang sudah di lakukan. Sudah terjadi sejenis disintegrasi keluarga yang menuntut sudah waktunya untuk menghidupkan kembali pendidikan watak atau pendidikan budi pekerti dan pendidikan nilai-nilai di lembaga pendidikan sejak taman kanak- 
kanak sampai dengan perguruan tinggi. Dengan demikian, sekolah telah berganti peran menjadi pengganti keluarga di dalam memperkenalkan nilai-nilai moral yang tidak lagi diperoleh oleh anak dalam keluarga. Dalam hal ini, sekolah telah mempunyai tugas ganda selain tugas pokoknya mengajar, tetapi juga mendidik. Dalam kehidupan keluarga yang tidak tentram, anak sukar untuk belajar. Oleh sebab itu, sekolah perlu memperhatikan atau mewujudkan suatu masyarakat moral dalam kehidupan sekolah yang membantu anak-anak, yang tidak memperolehnya lagi dalam lingkungan keluarganya.

Terkait mengenai faktor penghambat dan penunjang pelaksanaan pendidikan budi pekerti dalam menanggulangi kenakalan siswa di SMP Negeri 8 Malang ini, yang sudah di sampaikan oleh informan melalui hasil wawancara peneliti di SMP Negei 8 Malang, maka dari faktor penunjang tersebut semua itu tidak lepas dari pendekatan yang sudah dilakukan oleh kepala sekolah dan guruguru di SMP Negeri 8 untuk mendukung atau menunjang adanya implementasi pendidikan budi di SMP 8 Malang ini sehingga bisa menanggulangi kenakalan siswanya.

Dapat disimpulkan bahwa dalam pendidikan budi pekerti perlu adanya kedekatan emosional terhadap masingmasing siswa. Sehingga guru perlu mengerti latar belakang siswa-siswi, latar belakang keluarga dan lingkungan sosialnya. Hal ini dikarenakan dalam pendidikan budi pekerti harus menyesuaikan dengan watak dan karakter siswa dan tidak bisa disama ratakan. Pendidikan budi pekerti perlu memformulasikan pendekatan dan metode yang sesuai dengan karakter masingmasing siswa. Setiap siswa mempunyai keragaman dalam hal kecakapan maupun kepribadian. Dalam proses belajar mengajar, karakteristik para siswa sangat perlu diperhitungkan lantaran dapat mempengaruhi jalannya proses dan hasil pembelajaran siswa yang bersangkutan. Oleh karena itu adalah penting sekali guru mengenal dan memahami siswa dengan seksama. Tujuannya agar guru dapat menentukan dengan seksama bahanbahan yang akan diberikan, menggunakan prosedur (strategi dan metode) mengajar yang serasi, serta mengadakan diagnosis atas kesulitan belajar yang dialami siswa, membantu siswa mengatasi masalah pribadi dan sosial, memberikan bimbingan, menilai hasil belajar dan kemajuan belajar siswa, dan kegiatan-kegiatan guru lainnya yang bertalian dengan individu siswa. Hal ini didasarkan pada hakikat manusia yang memiliki kualitas karakter yang berbedabeda.

Pembentukan dan penanaman nilai-nilai kehidupan dalam kegiatan pembelajaran, di tuntut untuk keterlibatan dan kerja sama dari semua pihak. Khususnya bagi seorang guru atau pendidik untuk peroses penanaman nilai ini di tuntut adanya keteladanan. Keteladanan dalam konsisten berpikir dan bersikap dalam kehidupan sehari-hari. Tuntutan ini bukan berarti seorang guru atau pendidik harus menjadi malaikat atau manusia yang sempurna, melainkan manusia yang mempunyai sikap konsisten dalam sikap hidupnya, artinya terbuka untuk perbaikan, terbuka untuk menerima kritik dan masukan.

\section{Solusi yang di ambil Oleh Sekolah Dalam Mengatasi Faktor Penghambat Implementasi Pendidikan Budi Pekerti Dalam Menanggulangi Kenakalan Siswa Di SMP Negeri 8 Malang}

Setelah mengetahui dari semua masalah yang ada, analisa yang dilakukan oleh peneliti terhadap hasil wawancara terhadap informan di SMP Negeri 8 Malang dalam rangka untuk mengetahui solusi terhadap faktor penghambat implementasi pendidikan budi pekerti dalam menanggulangi kenakalan siswa 
di SMP Negeri 8 Malang. Dari hasil wawancara peneliti dengan informan ditemukan beberapa solusi salah satunya adalah harus di program dan diatur secara sistem dan harus ada kerjasama dengan semua komponen yang ada di sekolah SMP Negeri 8 Malang karena sebagai kepala sekolah tidak bisa berdiri sendiri dan melakukan semuanya sendiri harus ada dukungan dari komponen di SMP Negeri 8 Malang Penemuan solusi perlu dilakukan oleh pihak sekolah dalam setiap adanya masalah-masalah yang menjadi faktor penghambat implementasi pendidikan budi pekerti dalam menanggulangi kenakalan siswa di sekolah. Pihak sekolah haruslah teliti dalam mengidentifikasi apa saja yang menjadi faktor penghambat implementasi pendidikan budi pekerti dalam menanggulangi kenakalan siswa agar dapat segera memformulasikan konsep sebagai bentuk solusi yang akan diterapkan dalam pemecahan masalah. Dalam perumusan sebuah solusi dibutuhkan kerjasama yang solid serta kepedulian diberbagai pihak dengan kesadaran diri sebagai pemenuhan pendidikan bagi siswa sehingga mencetak lulusan yang sesuai dengan visi dan misi sekolah di SMP Negeri 8 Malang.

Solusi dalam mengatasi faktor penghambat implementasi pendidikan budi pekerti dalam menanggulangi kenakalan siswa di SMP Negeri 8 Malang ini sebelumnya harus diprogram dan di atur secara sistem dan harus bekerjasama antara kepala sekolah dengan semua pihak yang ada di dalam sekolah, hal ini dibenarkan oleh bapak kepala sekolah. Selain itu juga peran dari pemerintah sangat diperlukan agar pemerintah lebih memperhatikan dan harus peduli pada anak sebagai masa depan, karena anak merupakan aset bangsa entah 10 atau 15 tahun kedepan, sedangkan kalau pemerintah cuma asal-asalan mengejar target maka pemerintah tidak akan menemukan apapun, contoh kalau memang pemerintah itu serius menutup semua situs yang amoral di internet, maka pasti tidak akan ada lagi kenakalan-kenakalan siswa yang radikal, ini merupakan solusi yang disampaikan oleh guru PKn, sedangkan menurut guru agama Islam solusi yang di berikan dan yang di harapkan adalah bahwa semua yang mengikuti dan bergabung atau berdekatan dengan seseorang baik itu sekolah, masyarakat, orang tua ini harus bahu-membahu, bekerjasama untuk menjadikan anak itu yang baik, kalau di antara ketiga ini ada kesinambungan dan kerjasama yang baik maka tidak sulit untuk menjadikan anak itu memiliki budi pekerti yang bagus sehingga bisa menanggulangi adanya kenakalan siswa terutama karakter dan tingkah laku dari orang tua itu sendiri dan ini yang sangat utama adalah orang tua, karena anak banyak waktu bersamasama dengan orang tua.

Bahkan solusi yang di berikan oleh guru BK menyarankan harus bekerja sama dengan kepala sekolah, wakil kepala sekolah kesiswaan, kurikulum, dan semua guru bidang studi termasuk melibatkan semua guru-guru yang ada di SMP Negeri 8 Malang ini supaya pendidikan budi pekerti di SMP 8 ini bisa menanggulangi kenakalan siswa yang banyak terjadi. Sedangkan solusi yang di harapkan kepada sekolah oleh para siswa agar bisa mengatasi faktor penghambat implementasi pendidikan budi pekerti dalam menanggulangi kenakalan siswa di SMP Negeri 8 Malang ini supaya lebih di tingkatkan perhatiannya kepada siswa, lebih tekun lagi atas kenakalan siswa ini dan lebih teliti untuk melihat muridmuridnya yang semakin berkembang untuk menjadi lebih dewasa.

Secara keseluruhan dapat disimpulkan agar implementasi pendidikan budi pekerti dalam menanggulangi kenakalan siswa ini dapat tercapai sesuai harapan, harus dengan adanya contoh teladan, kebersamaan oleh semua pihak untuk membimbing seluruh siswa SMP Negeri 8 Malang secara terarah. Tidak hanya siswa berdiri 
sendiri namun antara guru dan siswa berdiskusi secara bersama dengan jalan ini diharapkan siswa dapat ikut serta dalam upaya pendidikan budi pekerti di sekolah. Yang utama adalah penanaman nilai agama dalam siswa, karena agama bagian norma yang sangat fundamental. Sehingga siswa memiliki kedewasaan spiritual sebagai landasan utama dalam upaya mendasari pendidikan budi pekerti. Keluarga awal terbentuknya kepribadian dari setiap peserta didik. Menurut Hartinah (2009:164) keluarga merupakan lingkungan pendidikan yang pertama dan utama bagi seorang anak (siswa). Pendidikan keluarga lebih menekankan pada aspek moral atau pembentukan kepribadian dari pada pendidikan untuk menguasai ilmu pengetahuan. Pada dasarnya pandangan keluarga-keluarga di Indonesia adalah pancasila, memang dalam hal mendidik anak itu dengan cara yang berbeda-beda karena setiap keluarga mempunyai karakter dan pandangan yang berbeda-beda dalam mendidik anaknya. Dengan dasar pancasila terutama sila pertama Ketuhanan Yang Maha Esa, siswa di tuntut untuk lebih mendekatkan diri kepada agama, karena setiap manusia ada hubungan secara horizontal yang mana hubungan sesama manusia dan hubunngan secara vertikal antara manusia dengan Tuhan. Supaya ada hubungan yang kuat antara individu dengan Sang penciptanya sesuai dengan keyakinan masing-masing.

Solusi dari lingkungan keluarga harus membuat nyaman anak (siswa) dengan implementasi pendidikan budi pekerti disetiap keluarga meskipun setiap keluarga dalam mendidik anaknya mempunyai cara tersendiri dalam mendidiknya, kemudian lingkungan masyarakatnya, teman bergaulnya juga menjadi sorotan penting dalam membentuk pribadi dan mental peseta didik. Sesuai dengan uraian yang sudah peneliti jabarkan, maka keluarga juga berperan dalam membentuk pribadi seorang anak, jadi untuk memulai perbaikan, maka harus dari diri anak itu sendiri dan keluarga, maka perbaikan harus dimulai dari yang paling sederhana, seperti selalu berkata jujur meski dalam gurauan, membaca dan setiap melakukan hal-hal kecil, memberikan bimbingan agama yang baik kepada anak dan masih banyak lagi, yang bisa dilakukan oleh keluarga. Jika di lingkungan sekolah gurulah yang menjadi figur dalam mencontoh perbuatan sesuai dengan pendidikan budi pekerti. Sekolah adalah lembaga pendidikan formal yang memiliki pengaruh kuat terhadap perkembangan anak, di antaranya adalah melakukan program pembinaan siswa melalui kegiatan-kegiatan keagamaan, kegiatan ekstrakurikuler yang ada di sekolah. Dengan usaha pembinaan yang terarah para siswa akan mengembangkan diri dengan baik, pikiran yang sehat akan mengarahkan para siswa kepada perbuatan yang pantas sopan dan bertanggung jawab yang di perlukan dalam menyelesaikan kesulitan atau masalah masing-masing.

\section{SIMPULAN}

Berdasarkan hasil penelitian dan pembahasan yaitu tentang "Implementasi Pendidikan Budi Pekerti dalam Menanggulangi Kenakalan Siswa di SMP Negeri 8 Malang" maka hasil penelitian ini dapat disimpulkan sebagai berikut: Implementasi pendidikan budi pekerti dalam menanggulangi kenakalan siswa di SMP Negeri 8 Malang sudah sesuai dengan Visi dan Misi dari SMP Negeri 8 Malang, yang mempunyai Visi Generasi Bangsa yang Bermartabat, Unggul Dalam Prestasi Berdasarkan Pada Iman Dan Taqwa, dan Berwawasan Lingkungan, sedangkan Misi Sekolah SMP Negeri 8 Malang adalah Meningkatkan Kinerja Tenaga Pendidikan Dan Tenaga Kependidikan (Professional); Mengoptimalkan Proses Pembelajaran Baik Intra Maupun Ekstrakurikuler (Enjoyable Learning); Menciptakan 
Lingkungan Sekolah Yang Kondusif Untuk Proses Pembelajaran (Green, Clean, Hygiene).

Implementasi pendidikan budi pekerti dalam menanggulangi kenakalan siswa di SMP Negeri 8 Malang ini sudah berjalan dengan baik, lancar dan terkendali, banyak sekali kebijakan-kebijakan dan pendekatan-pendekatan yang di lakukan oleh sekolah dalam menunjang adanya implementasi pendidikan budi pekerti dalam menanggulangi kenakalan siswa di SMP Negeri 8 Malang, yang mana di integrasikan juga kedalam budaya sekolah seperti budaya bersih, jujur, sopan santun, disiplin dan budaya peduli lingkungan. Selain itu banyak sekali nilai-nilai yang di kembangkan dalam pendidikan budi pekerti di SMP Negeri 8 Malang contohnya nilai-nilai kedisiplinan, kejujuran, saling menghormati orang lain, kepedulian, kerjasama dan tanggung jawab bahkan nilai-nilai religiusitas.

Implementasi pendidikan budi pekerti dalam menanggulangi kenakalan siswa di SMP Negeri 8 Malang ini juga dimasukkan atau in-klud dalam semua mata pelajaran tidak hanya melalui pelajaran PPKn ataupun pelajaran Agama Islam saja tetapi implementasi pendidikan budi pekerti semua guru bidang studi sudah memasukkan unsur-unsur penanaman pendidikan budi pekerti dalam setiap pelajaranyang sudah mengembangkan dan mengajarkan tentang pentingnya pendidikan budi pekerti pada anak sehingga membentuk anak yang berbudi pekerti luhur. Selain in-klud pada semua bidang studi implementasi pendidikan budi pekerti dalam menanggulangi kenakalan siswa di SMP Negeri 8 Malang juga sudah di laksanakan melalui kegiatan ekstrakurikuler yang sudah ada, seperti ekstrakurikuler keputrian, BTQ (Baca Tulis Al-Qur'an), kegiatan membaca do'a dan Asmaul husna setiap pagi sebelum pelajaran di mulai, kegiatan membaca surah al-waqi'ah dan kultum setiap jum'at bagi yang muslim, sedangkan bagi yang non-muslim dengan mewajibkan membaca kitabnya masing-masing, selain itu implementasi pendidikan budi pekerti dalam menanggulangi kenakalan siswanya juga melalui ekstrakurikuler lainnya seperti: ekskul pramuka, PMR (Palang Merah Remaja), Olahraga, paskibra dan karate. Semua itu untuk mendukung dan menunjang adanya pelaksanaan pendidikan budi pekerti dalam menanggulangi kenakalan siswa di SMP Negeri 8 Malang.

Kenakalan siswa merupakan perbuatan atau tingkah laku yang menyimpang dari norma yang sudah berlaku dalam suatu masyarakat. Kenakalan yang di lakukan oleh siswa di SMP Negeri 8 Malang ini masih dalam batas yang sewajarnya tidak sampai melampaui batas yang sangat merugikan diri sendiri, seperti halnya narkoba atau memakai obat-obatan terlarang, adapun kenakalan siswa yang banyak di lakukan di SMP Negeri 8 Malang ini adalah tidak taat pada aturan, tidak disiplin (berpakaian tidak sesuai aturan, rambut tidak rapi, sepatu tidak warna hitam atau warna wajib, suka terlambat datang ke sekolah), banyak siswa yang berpacaran, mengolok-olok guru, suka mengganggu temannya dan membawa HP ke sekolah.

Faktor penyebab kenakalan siswa yang banyak di lakukan oleh siswa SMP Negeri 8 Malang diantaranya karena siswa masih mencari jati diri mereka yang sebenarnya dimana anak masih labil, selanjutnya terpengaruh dengan lingkungan luar antara lain lingkungan masyarakat, dimana banyak sekali perbuatan-perbuatan yang amoral yang memberikan contoh tidak baik kepada anak, pergaulan dengan teman diluar sekolah yang sudah membuat geng atau kelompok-kelompok tertentu, dan bahkan yang banyak terjadi karena pengaruh teknologi dan media massa yang semakin canggih sehingga tidak menutup kemungkinan siswa banyak 
menyalahgunakan penggunaan teknologi yang semakin canggih tersebut, selajutnya tidak kalah pentingnya adalah keseharianya dirumah yaitu lingkungan keluarga.

Faktor Penghambat Dan Penunjang yang dihadapi Dalam Implementasi Pendidikan Budi Pekerti Dalam Menanggulangi Kenakalan Siswa Di SMP Negeri 8 Malang. Faktor penunjang dalam implementasi pendidikan budi pekerti di SMP Negeri 8 Malang adalah: Adanya dukungan dari seluruh komponen yang ada di sekolah SMP Negeri 8 Malang mulai dari kepala sekolah, semua guru di SMP Negeri 8 Malang dan bahkan staff Tata Usaha dan seluruh pegawai di sekolah SMP Negeri 8 Malang. Dukungan dari sebagian orang tua murid itu sendiri, sehingga untuk membentuk budi pekerti siswa yang baik dan berbudi pekerti luhur itu sangat mudah. Sistem Pendidikan di sekolah yang memasukkan unsur-unsur penanaman nilai pendidikan budi pekerti pada semua mata pelajaran. Faktor penunjangnya juga melalui Kegiatan Ekstrakurikuler yang sudah menjadi program kegiatan unggulan dari SMP Negeri 8 Malang yang dimana melalui kegiatan ekstrakurikuler ini siswa bisa mengasah potensi dan kepribadiannya terutama dalam implementasi penanaman pendidikan budi pekerti di SMP Negeri 8 Malang. Sedangkan Faktor Penghambat dalam Implementasi Pendidikan Budi Pekerti dalam Menanggulangi Kenakalan Siswa di SMP Negeri 8 Malang adalah disebabkan dari faktor lingkungan keluarga (orang tua) yang tidak memberikan contoh atau teladan yang baik bagi anaknyadan juga tidak mendukung dalam membentuk budi pekerti yang baik bagi anaknya Sehingga disinilah peran dari sekolah atau guru itu sendiri, karena keluarga yang secara tradisional merupakan guru pertama dari setiap anak-anak, mulai kehilangan fungsinya, selain itu juga faktor dari lingkungan masyarakat yang tidak adanya kesinambungan dengan sekolah untuk menanamkan pendidikan budi pekerti pada siswa dalam menanggulangi kenakalan siswa di SMP Negeri 8 Malang ini. Oleh karena itu perlu adanya kata sepakat dan kerjasama serta kesinambungan antara guru, orang tua murid dan bahkan lingkungan sekitar yaitu masyarakat mengenai implementasi pendidikan budi pekerti yang baik, karena semua itu juga harus diperhatikan.

Faktor penghambat lainnya dalam implementasi pendidikan budi pekerti dalam menanggulangi kenakalan siswa di SMP Negeri 8 Malang ini disebabkan karena makin fulgarnya media di luar yaitu internet yang anak mudah mengakses halhal yang menyebabkan semakin hancurnya moral anak bangsa. serta faktor media massa yang semakin canggih, yang sudah tidak mendidik lagi baik dari film maupun acara yang lainnya. Solusi yang di ambil oleh sekolah dalam Mengatasi Faktor Penghambat Implementasi Pendidikan Budi Pekerti dalam Menanggulangi Kenakalan Siswa Di SMP Negeri 8 Malangini adalah harus diprogram dan di atur secara sistem dan harus bekerjasama antara kepala sekolah dengan semua pihak yang ada di dalam sekolah, Selain itu juga peran dari pemerintah itu sendiri sangat diperlukan agar pemerintah lebih memperhatikan dan harus peduli pada anak sebagai masa depan.Sedangkan kalau pemerintah cuma asal-asalan mengejar target maka pemerintah tidak akan menemukan apapun, contoh kalau memang pemerintah itu serius menutup semua situs yang amoral di internet, maka pasti tidak akan ada lagi kenakalan-kenakalan siswa yang radikal. Solusi yang di ambil oleh sekolah dalam mengatasi faktor penghambat inplementasi pendidikan budi pekerti dalam menanggulangi kenakalan siswa di SMP Negeri 8 Malang harus ada kerjasama dan berkesinambungan antara keluarga (orang tua) sekolah, dan masyarakat untuk menjadikan anak berbudi pekerti baik. 
Solusi lain adalah harus bekerja sama dengan kepala sekolah, wakil kepala sekolah kesiswaan, kurikulum, dan semua guru bidang studi termasuk melibatkan semua guru-guru yang ada di SMP Negeri 8 Malang untuk mengatasi faktor penghambat implementasi pendidikan budi pekerti dalam menanggulangi kenakalan siswa di SMP Negeri 8Malangdan supaya lebih di tingkatkan lagi perhatiannya kepada siswa, pengawasannya harus lebih teliti dan intensif lagi atas kenakalan siswa yang terjadi dan lebih teliti untuk melihat murid-muridnya yang semakin berkembang untuk menjadi lebih dewasa. Selanjutnya peneliti akan memberikan beberapa saran yang merupakan masukan mengenai "Implementasi Pendidikan Budi Pekerti Dalam Menanggulangi Kenakalan Siswa Di SMP Negeri 8 Malang" untuk kedepannya.

\section{DAFTAR PUSTAKA}

Elmubarok, zaim. 2008. Membumikan Pendidikan Nilai Mengumpulkan Yang Terserak Menyambung Yang Terputus Dan Menyatukan Yang Tercerai. Bandung: Alfabeta

Mulyasa, E. 2002. Manajemen Berbasis Sekolah. Bandung: PT. Remaja Rosdakarya.

Moleong, J Lexi. 2002. Metodologi Penelitian Kualitatif. Bandung: Remaja Rosdakarya

Naim, Ngainun dan Sauqi, Ahmad. Pendidikan Multikultural Konsep dan Aplikasi. Jogjakarta: Ar-ruzz Media.

Redaksi Kompas. 2002. Penanaman Budi Pekerti Bukan Hanya Tugas Guru. Harian Kompas. Rabu, 3 Mei 2000.

Sudarsono. 1995. Kenakalan Siswa. Jakarta: Rineka Cipta.

Shafique Ali Khan. 2005. Filsafat Pendidikan Al-Ghazali. Bandung: Pustaka Setia.

Suwaid, Muhammad. 2009. Mendidik
Anak Bersama Nabi SAW. Solo: Pustaka Arafah.

Suparno, Paul. Dkk. 2002. Pendidikan Budi

Pekerti di Sekolah suatu Tinjauan Umum. Yogyakarta: Kanisius.

Tim Penyusun Kamus Pusat Bahasa. 2008.

Kamus Bahasa Indonesia. Jakarta:

Departemen Pendidikan Nasional.

Tim Dosen FKIP UMM, 2010. Bahasa Indonesia Untuk Karangan Ilmiah (Makalah, Skripsi, Tesis, Desertasi). Malang : UMM Press.

Tilaar, H.A.R. 1999. Beberapa Agenda

Reformasi Pendidikan Nasional dalam Perspektif Abad 21. Magelang: Tera Indonesia

UUSPN (SISDIKNAS). 2003. UndangUndang No. 20 Tahun 2003 Tentang Sistem Pendidikan Nasional (SISDIKNAS). Bandung: Citra Umbara.

Wikipedia. Pendidikan .2010. Diakses dari http://id.wikipedia.org/wiki/. Pada Tanggal 30 Desember 2013.

Yulianingsih dan Ismantoro. 2002. Dengan Budi Pekerti Mendidik Anak Didik Seutuhnya. Suplemen Republika, Sabtu, 11 Mei 2002.

Zuriah, Nurul. 1997. Urgensi Pendidikan Budi Pekerti Bagi Dunia Pendidikan Kita (Harapan dan Tantangan Menyongsong Era Globalisasi Dunia). Dalam Majalah Suara Muhammadiyah No. 15/82/1997: Yogyakarta.

Zuriah, Nurul. 2005. Metodologi Penelitian Sosial dan Pendidikan: TeoriAplikasi. Jakarta: PT. Bumi Aksara.

Zuriah, Nurul. 2009. Metodologi Penelitian Sosial dan Pendidikan: TeoriAplikasi. Jakarta: PT. Bumi Aksara.

Zuriah, Nurul. 2011. Buku Pendidikan Moral dan Budi Pekerti dalam perspektif perubahan (Menggagas Platform Pendidikan Budi Pekerti secara kontekstual dan Futuristik). Jakarta: PT. Bumi Aksara. 